legislativas, dotando o ordenamento jurídico mercantil de uma resistência vital, que faz pensar, não já na absorção pelo direito administrativo, mas, ao contrário, na comercialização do direito público".

Em verdade, êsse fenômeno pode bem advertir-se na Rússia soviética, onde as emprêsas do Estado são planificadas e estrutu radas nos moldes da economia capitalista e têm sua disciplina jurídica no código civil e comercial daquêle país.

13. - Parece, portanto, prematuro, falar no iminente desaparecimento do direito comercial. Os novos fatos e relações estarão, por certo, a aconselhar uma revisão de princípios e conceitos, como ainda há pouco sugeriu o professor VAN RYN (19) da Universidade Livre de Bruxelas, no concurso de conferências ali realizado. Mas, se isso é labor de futuro, iá agora pode o jurista, como ensina o professor HAMEL, exigir que as pessoas de direito público tenham comportamento condizente com a nova situação. Se o Estado se converte em indus trial, transportador, segurador, banqueiro, deve atuar como atuaria o comerciante, o particular. Os juristas do direito comercia - preleciona o mestre parisiense - devem ser estritamente rígidos neste ponto: devem limitar a intromissão do direito público no direito privado, exigindo que o Estado, ao converter-se em comerciante, banqueiro e segurador, se conduza exatamente como um comerciante privado, um banqueiro privado ou segurador privado. Do contrário, as conseqüências seriam muito graves: graves, em primeiro lugar, do ponto de vista da emprêsa regida pelo Estado, que correria sem dúvida o risco de ter funestos resultados (20); graves, também, pelo que se refere à liberdade e independência dos cidadãos que, no terreno econômico comercial, não devem ser objeto de diferenciacõos que não surjam diretamente da própria vida comercial". (21)

(19) - Revue Trimestrelle de Droit Commercial, 1953, pgs. 565 e segts. com graves danos para o erário público e, em última analise, para a
fortuna particular, de onde são tirados os recursos para o financiamento

(21) - Os estabelecimentos montados pelo poder público para o exercício do comércio, a pretêxto de promover o barateamento do preço de utilidade de consumo necessário, fazem concorrência desleal aos negociantes par
ticulares, mercê dos favores de que desfrutam e, não raro, bem minguados são os resultados que apresentam.

\section{A INSEMINAÇÃO ARTIFICIAL EM FACE DA MORAL E DO DIREITO}

\author{
ARMANDO DIAS DE AZEVEDO \\ Catedrático de Direito Civil
}

\begin{abstract}
1. Posição do problema. - 2. Na escala animal. 3. O problema na espécie humana. - 4. Opiniões de escritores. - 5. Opiniões de juristas. -6 . Distinções e conceitos. - 7. A inseminação artificial própria e os moralistas. - 8. A inseminação artificial imprópria e os moralistas. - 9. A palavra de Pio XII aos médicos. - 10. A palavra de Pio XII às parteiras. - 11. A palavra de Pio XII aos membros de um Congresso Científico. - 12. Opiniões dos protestantes. - 13. Outras advertências contra a hétero-inseminação. - 14. A inseminação artifical humana e os regimes totalitários. - 15. - A inseminação homóloga e o direito. - 16. A inseminação heteróloga e o direito. - 17. No campo do direito de família. - 18. Revisão dos textos legais vigentes de direito civil. - 19. A adoção como remédio legal. - 20. Hétero-inseminação e adultério. - 21. Héteroinseminação e injúria grave. - 22. A inseminação artificial e o estupro. - 23. Revisão do Código Penal. - 24. Responsabilidade dos médicos. - 25. Conclusões.
\end{abstract}

1. Por demais chocantes são os contrastes que nos oferece a época tormentosa que atravessamos, com o espetáculo da humanidade, ébria de tecnicismo à outrance (1), impregnada de materialismo, desorientada pelo amoralismo, idólatra do cientificismo. 
Em nome duma falsa ciência biológica, faz-se a defesa de aberrações morais, tais como o neo-maltusianismo e o abôrto, quer terapêutico, quer profilático, a que presta seu concurso dialético uma pretensa ciência econômica desumana e, por isso mesmo, não menos falsa.

E agora, paradoxalmente, a ciência biológica (2) se nos apresenta visando resultado contrário, isto é, em vez de diminuir a natalidade, auxiliar e incrementar a geracão de novos seres humanos, por artifícios técnicos, não recuando muitos - talvez a grande maioria - de seus fautores ante o emprêgo de processos aberrantes da moral e que rebaixam o homem ao nível do animal.

E' admissível, por artifícios técnicos, que respeitam a moral, facilitar a fecundação da mulher pelo marido. Na espécie humana, ir além importa em violar os princípios éticos e os do direito natural.

2. Na escala animal, nada obsta a que se pratique a inseminação artificial, sem quaisquer outras cogitações ou limites que os da utilidade e do respeito ao direito de propriedade, de vez que os irracionais, que podem ser objeto de tal direito, não são sujeitos de direitos, nem estão subordinados à lei moral, o que constitui, na ordem natural, apanágio do homem. E' isso, aliás, corolário impostergável do maior dom com que foi o homem agraciado por Deus - a racionalidade, a liberdade. Os brutos, ao contrário, só estão sujeitos à lei inexorável do instinto.

Sem falar nas experiências que os árabes teriam feito, no século XIV, com cavalos de raça, podemos dizer que foi um sacerdote italiano dos fins do século XVIII, o padre LÁZARO SPALLANZANI, dedicado aos estudos de biologia, o precursor

(2) Nấo é de se desprezar o concurso que a biologia pode trazer à ciência jurídica, e aí estão para o comprovar, os estudos do Prof. NERSON (apud he Droit Privé

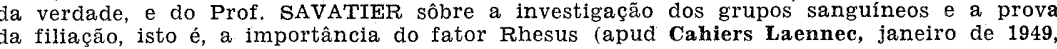
pgs. 15-25), mas não devemos esquecer a lição de RENARD:

apenas uma perspectiva sôbre problema da vida; além disso, suas sugestóes só nos podem servir filtradas através de Le droit, l'ordre et la raison, pg. 223)

E, exemplificando, lembra o saudoso jurista-filósofo que "todo o título da pacomo os prazo cundação. Há séculos e séculos que os . Códigos têm por certa a unidade da paternipresuncão de ordem pública Admite, pois, o eminente professor de Direito Público dai Universidade de Nancy,
Admesmo dos firhos nascidos fóra do casamento" (a., o. pits.) que findou seus dias na Ordem Dominicana, que "os trabalhos dos biologistas podem evem ajuar nos a fazer progrealr m momento em que se tenha de "encarar uma adaptação do Código aos progressos da ciência fisiológica" (pg. 224). da inseminacão artificial, pois foi quem, com sua experiência no reino animal, demonstrou a possibilidade da gestacão sem contacto direto dos germens do macho e da fêmea (3).

Desde então, as pesquisas e as experiências se multiplicaram e aperfeiçoaram a tal ponto que, hoje, na criação animal, é processo corriqueiro.

3. Transplantando tais processos para o campo da espécie humana, o assunto já chegou, em fins do século passado, a preocupar o Santo Ofício, que, a 24 de marco de 1897 , tendo em vista os métodos, então, preconizados para a obtenção do semen humano, concluíu negativamente, quanto à liceidade moral da fecundação artificial da mulher (4).

4. O assunto, nos últimos tempos, se tornou de tão palpitante atualidade, os aperfeicoamentos técnicos do processo de inseminação artificial progrediram tanto, os problemas morais relativos a tudo o que se refere à vida conjugal passaram a ser estudados com tanto afinco e com tanta franqueza, suas repercussões jurídicas, morais, sociais, políticas e econômicas im pressionaram tanto aos juristas, aos moralistas, aos sociológos, aos estadistas, aos políticos e aos economistas, que "o drama humano" da inseminação artificial se projetou, conseqüentemente, na arena dos debates apaixonantes do século, espraiando-se das páginas austeras das revistas e dos livros de ciência médica, jurídica, sociológica e teológico-moral para as colunas dos grandes jornais e das revistas populares, para o palco do teatro, a tela do cinema, o romance e o ensaio.

GIOVANNI PAPINI, em sua obra $O$ livro negro, em que nos apresenta a continuação do Diório de Gog, pinta-nos, com a cínica brutalidade de conceitos de seu personagem, com inteiro

(3) RAYMOND RAMBAUR, Le drame humain de l'insémination artifieielle, pg. 13; Linsemination artificielle (coletanea pubicada pelo "Centre d'Elude Laennec"), pg. 87 Dr. FRANCISCO PLARO, Deonter stérilité fééminine, Dé, 28; G. ABRUZZESE, La fecondazione artifielale umana, pgs. 132-136. CHALIER prefere a expressão inseminacão artificial, porque fecundação artificial prejulga o resultado, ao passo que aquela "não ultrapassa o poder de nosso gesto, que líquido espermático que sabemos conveniente, e que transportamos a caminho do óvulo mas sem que possamos nada sôbre a fusấo intima dos dois gametos, que constitui fecundaçáa. Nosso papel è um pouco comparavel ao dum agente matrimonial que (asto um em presenca do outro" (CHALIER, La stérilité conjugale, pg. 171).

(4) Doeumentation Catholique, vol. 42, pg. 505, nota 1. V. também o artigo L'in(4) 
realismo, o profissional "doador" de esperma (5), o "garanhão humano", o "pai de cem filhos", que lhe desconhecem a existência "e que nunca verá", o que "tem cem filhos e está só", o que "tornou mães cem mulheres e não é amado por nenhuma", o enfêrmo que "logo que ficar restabelecido, terá de voltar ao seu ofício de reprodutor diplomado" (6).

GABRIEL MARCEL, o conhecido dramaturgo e filósofo francês, que há pouco tempo visitou o Brasil, usa de linguagem não menos enérgica, quando, ao tratar das incidências psicológicas a morais da inseminacão artificial e ao aludir ao processo de masturbação para a obtenção do líquido seminal, qualifica o doador

(5) O têrmo, já consagrado, de doador, idêntico ao usado na transfusão de sangue, tem dado margem a que se procure assimilar a inseminação a uma transfusão de sangue, mas, como muito bem diz GABRIEL MARCEL, "manlfesta é a diferença entre
fato de se deixar tomar sangue com um fim determinado e o de provocar, por masturbaçăo, uma emissão de esperma" (apud C. E. Laennec, L'insémination artificielle, pg. 37 ).

Se há doadores, teremos, ad instar dos bancos de sangue, bancos de semen. humano como a liengagem val abalxo da de me umano como matéria prima.

puns países, năo seria de espantabelecer uma legislação regulamentadora (o que em tação da prostituição), então, como diz o Prof. THELIN, de Lausanne, a "a inseminaçãa rtificial lomaria imediatamente caráter institucional, regido pelo direito público, com deria pouco a pouco seu poder de modo incompativel com os direitos estritamente pessoais inerentes ao indivíduo" (apud RAMBAUR, Le drame humain de l'insémination ar-

Teriamos métodos de haras, na expressão do Cardial GRIFFIN (Documentation Teriamos métodos de haras, na expressão do
Catholique, vol. 42 , pg. 505 ). Seria a desumanizacão

Falando sôbre a inseminação artificial, o célebre orador e escritor francês $\mathbf{P}$. PAUL COULET, S. J., que, antes da segunda guerra mundial, empolgou a capital brapreside à transmissão da vida" (PAUL COULET, Les problèmes de la fécondation humaine, pg. 25), colimando "suprimir pura e simplesmente o papel do pai na obra" de tal transmissáo, com o risco "prón para o próprio amor humano" (pg. 27). Profliga o horror de querer reduzir o homem o "papel pessoal e degradante de simples fornecedor de vida", o que importaria em en ",

Náo menos sugestivas são as palavras do Prof. J. FERNANDO CARNEIRO:

"O processo de degradação moral resultante do materialismo, combinado com êsse culto da techica, esta preparando osuma artificial, cesarianamente extraído, psicotècnicamente classificado e aproveitado pelo Serviço Público, morto por eutanásia quando a sociedade julgou oportuno e finalmente (a) Tais as aberracōes que a fantasia delirante de certos "sabios" sob c ciência, propina, que um professor da Universidade de Virgínia, o Dr. BRITTÓN, chega a imaginar a possibilidade de fecundar com semen humano uma fêmea de antropoide tuir raca intermedíria entre o homem e o macaco (apud RAMBAUR, que E' o cúmulo: já năo bastaria o absurdo de descender o homem do macaco; o homem

(6) G. PAPINI, O livro negro (ed. em português), pgs. 47-48.
G de "prostituto do onanismo", quando age como profissional (7), e o ridiculariza quando na hipótese de agir por filantropia (?!), o considera "puro animal reprodutor", e, irônicamente, apontandoo como "benfeitor da humanidade", pergunta porque, no curso duma cerimônia oficial, não se lhe colocaria ao peito "uma medalha pelos records da masturbação humanitária", acrescentando que "quando o homem se comporta como animal, cai muito abaixo do animal" (8).

5. O problema humano da inseminação artificial se tornou tão agudo, pela propagação que tal método vem tendo nos Es* tados Unidos, na Inglaterra e na França (9), que Sua Santidade - Papa PIO XII já o abordou frontalmente, em dois discursos públicos, isto é, na alocução, de 29 de setembro de 1949 , aos membros do $4^{\circ}$ Congresso internacional dos médicos católicos (10) e na alocução, de 29 de outubro de 1951, às parteiras (11).

$\mathrm{Na}$ magnífica coletânea de estudos, publicada, sob o título de Le droit privé français au milieu du XX siècle, em 1950, pela Faculdade de Direito de Paris, em homenagem a seu antigo decano, o eminente Professor GEORGES RIPERT, por ocasião de seu 70 aniversário natalício, e na qual colaboraram as maiores figuras da ciência jurídica francesa, o Professor ROGER NERSON, da Faculdade de Direito de Grenoble, ao tratar das repercussões dos progressos científicos sôbre o direito de família, aflorou o tema da inseminação artificial, apontando-lhe as conseqüências jurídicas (12), estigmatizando êsse rebaixamento do homem ao papel de "portador de germens" e da mulher à categoria de "máquina de gestação", quando o casamento "não é apenas a união sexual, - meio de perpetuar a raça, mas também um ato de caráter moral" (13).

RENE' SAVATIER, o eminente professor da Faculdade de

(7) Nos Estados Unidos, a remuneração dum "papai optimun" variaria entre cem e trezentos dólares, por doação (Diário de Notícias, de Pôrto Alegre, 9 de abril de 1952).

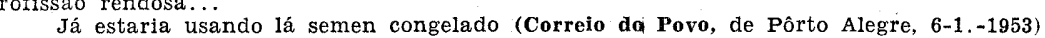
Na Dinamare cogitar-se-ia

viúvas e divorciadas. (Diário de Notícias, de 15-4-1953).

(8) C. E. Laennec, L'insémination artificielle, pgs. 37-39.

(9) Estatisticas recentes chegam a falar em 80.222 criancas produzidas por tal Notíclas, cit.) pode, com duas emissốes semanais, gerar no mesmo ano 20.000 filhos, pergunta se não ponsabilité médicale, $\mathrm{pg}$. 6).

de Seria produção em massa, per.

cros fabulosos para "tubaróes" $\ldots$.
(10) Documentation Catholique, vol. 46, pgs. 1345-1350.

(11) Documentation Catholique, vol. 48, pg. 1489 .

ges Ripert), ng. 15-21, pgs. 415-422.
(13) Le Droit Privé Français, n.o 21, pg. 41 .. 
Direito de Poitiers, ao que parece, é o jurista francês a quem mais preocupa o problema, do ponto de vista jurídico, sem descurar o aspecto moral, que não pode, aliás, ser jamais desprezado pelo cultor do direito, a quem seria indesculpável desconhecer que direito e moral, embora distintos, não podem ser tratados como compartimentos estanques. $\mathrm{O}$ tema da inseminação artificial é versado em várias de suas últimas monografias (14).

A atualidade e a importância do problema moral e jurídico da inseminação artificial levaram-nos a, em breve síntese, apresentá-lo aos círculos jurídicos brasileiros, abrindo, em nosso meio cultural, o debate, sem fugirmos, desde já, a uma tomada de posição, que fazemos convictamente contra qualquer solução que vá de encontro à moral cristã que informa o nosso direito de família.

6. Encarada do ponto de vista jurídico-moral, a inseminação artificial humana, também por outros chamada fecundação artificial, pode ser homóloga (auto-inseminação), quando se utilize o esperma do marido, para fecundar a mulher, ou heteróloga (hétero-inseminação), quando se empregar o dum terceiro (doador), para tal fim (15).

Partindo de dados puramente biológicos, a inseminacão artificial pode ser classificada como própria (pròpriamente dita) e imprópria (impròpriamente dita) (16).

7. A inseminação artificial pròpriamente dita pode ser obtida por duas maneiras: 1) pela cópula interrompida com ejaculação extra vasum femineum e injeção in cavitatem uteri, isto é, por onanismo; 2) sem cópula, ejaculando o homem num recipiente, para aí ser coletado o líquido a ser injetado na mulher, isto é, por masturbação ou polução voluntária (17).

14) RENE' SAVATIER, L'insémination artificielle devant le droit positif français (pgs. 35-34 da coletênea L'insémination artificielle, publicada pelo "Centre d'Études Laennec"; Les métamorphoses économiques et sociales du Droit Civil d'oujourd'hui (n.o 173,
pgs. 135-137); La responsabilité médicale (conferências na Faculdade de Direito da Unipgs. 135-137) ; La responsabilité médicale (conferências na Faculdade de Direito da Uni-
versidade de Louvain, em 1948, pgs. 6 e 19-21). Embora não versando a a inseminacão artificial, são também interessantíssimos como visão panorâmica do Direito Civil hodierno os estudos Réalismee et idéalissme au Droit Ci-
vil d'aujourd'hui - structures matérielles et structures juridiques (apud Le Droit Privé vil d'aujourd'hui - structures matérielles et struetures juridiques (apud Le Droit Privé
Français, vol. I, pgs. 75-92) e a monografia Da Droit Civil au Droit Public, em que no campo do direito da familia, aponta e utiliza SAVATIER as conquistas da ciência biológica moderna, ao passo que, numa publicacáo dos Cahlers Laennec sôbre o "factor
Rhesus", estuda o aspecto juridico da "Recherche des groupes sanguins et preuve de
la filiation" (Cahiers Laennec, janeiro 1949, pgs. 15-25). (15) JAIME PUJIULA, La insemination y su trascendencia (Digesto Católico, Bue-
nos Aires, n.o 62, novembro 1952, pgs. 72-77; RAYMOND RAMBAUR, Le drame de l'insémination artificielle, passim)

(16) F'RANCISCO PEIRO;, Deontologia médica, ns. 115-116, pgs. 214-216. main de l'insêmination artificielle, pgss. 161-165; Dr. HENRI BON, Medicina católica, pg. 582
Ambos êsses modos são imorais, quer se trate de inseminação homóloga ou heteróloga.

"Sendo a masturbação e o onanismo em si mesmos atos maus - escreve o eminente Professor J. FERNANDO CARNEIRO nunca podem ser usados como recursos para a colheita do semen humano, ainda que a finalidade da colheita fôsse nobre, fôsse por exemplo, para fins de diagnóstico, ou para inseminação artificial homóloga em casal que desejasse ter filhos" (18).

8. A inseminação artificial impròpriamente dita - ensina - Dr. FRANCISCO PEIRO', professor da Faculdade de Medicina da Universidade de Madrid - pode operar-se por três processos: 1) dilatação da vagina, por meios mecânicos adequados, para efetuar a cópula normal, quando a vagina for apertada; 2) realização normal da cópula e da ejaculação dentro da vagina e coleta do esperma para injeção posterior intra cavitatem uteri; 3 ) punção nos testículos ou no epidídimo do homem ou leve massagem, para injetar o líquido seminal na mulher (19).

Os dois primeiros processos, quando empregados na autcinseminação, são, unânimemente, considerados lícitos pelos moralistas, havendo, porém, discussão sôbre o terceiro, pois "uns consideram-no ilícito, porque é obtido sem que se realize o ato normal instituído pela natureza para a procriação, ou seja a cópula", so passo que "outros admitem-no e autorizam-no, pois o fim do ato conjugal, ou seja a procriação, é conseguido sem sensação venérea de qualquer espécie" (20), nem onanismo, nem masturbação, nem polução voluntária.

"A fecundação obtida por meio de punção - ensina PEIRO' - não se considera viável. Os espermatozoides não possuem vitalidade, nem sequer mobilidade, se não estiverem em contacto com o líquido prostático. A próstata tem como finalidade imprimir movimento e atividade aos espermatozoides. $\mathrm{O}$ espermatozoide que não passa por ela morre" (21).

Outros autores aludem ao "processo de Courty", que "con. siste em se servir, para o ato conjugal, dum preservativo, em que - médico achará, depositado pelo marido, o esperma asséptico necessário e o projetará mais a fundo nas vias femininas" (22).

O método é discutidíssimo pelos moralistas, manifestando-se

(18) J. FERNANDO CARNEIRO, artigo sôbre Eutanásia na revista "A Ordem", vol.

(19) PEIRO', Deont. méd., n.o 116, pg. 215.

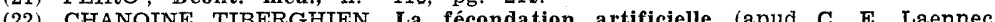


contrários a êle o P. VERMEERSCH (23) e o P. PAYEN (24), ao passo que o P. TESSON (25) e o Cônego TIBERGHIEN (26) se inclinam pela sua liceidade na auto-inseminação.

A natureza e os moldes dêste estudo não comportam anális pormenorizada dos processos, bastando referir que à objeção dos primeiros, quanto à anormalidade, respondem os outros que issn não implica ilegitimidade.

Repugna-nos tal método, pelo uso do preservativo, que nos parece ir contra a natureza, por impedir o contacto natural entre o órgão genital masculino e o feminino, que constitui a intimidade essencial ao ato conjugal.

Os métodos impróprios só serão morais, quando se tratar de auto-inseminação, isto é, quando usado o líquido seminal do marido, sendo sempre imoral a hétero-inseminação, quaisquer que sejam os processos adotados.

9. E aqui vem a pêlo citar os princípios firmados por Sua médicos:

Santidade o Papa PIO XII (27), em sua alocução aos

"1" A prática dessa fecundação artificial, quando se trata do homem, não pode ser considerada, nem exclusivamente, nem principalmente, do ponto de vista biológico e médico, deixando de lado o da moral e do direito.

" 2 ' A fecundação artificial fora do matrimônio é condenável, pura e simplesmente, como imoral.

"Tal é, com efeito, a lei natural e a lei divina positiva, que a procriação duma nova vida só pode ser fruto do matrimônio. Só o matrimônio salvaguarda a dignidade dos cônjuges (principalmente da mulher, no caso presente), dignidade essa que é bem pessoal de ambos. Em si, só êle provê ao bem e à educação do filho.

"Por conseguinte, sôbre a condenação duma fecundação artificial fora da união conjugal, nenhuma divergência de opiniốes é possível entre católicos. O filho concebido em tais condiç̃es, pelo fato mesmo, é ilegítimo.

"3" A fecundação artificial no matrimônio, mas produzida por elemento ativo dum terceiro, é, igualmente, imoral, e, como tal, absolutamente reprovável.

(23) VEERMERSCH, De castitate, pg. 405.
(24) PAYEN, De matrimonio, n.o 3, s. 2 .
(25) TESSON, L'insémination artificielle et la morale (apud C. E. Laennec, L'insém. (25) TESSON, L'insémination artificiell
artif., pgs. 89-93).
(26) TIBERGHEN, eit., pgs. 107-118

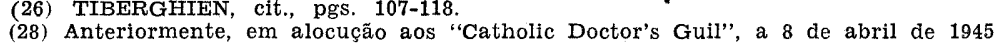
s. Eminência o Cardial GRIFFIN, Arcebispo de Westminster, qualificou a hétero-inse-

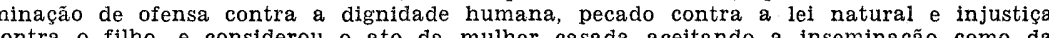
contra o filho, e considerou o ato da mulher casada aceitando a inseminação como da
mesma malícia moral que o adultério (Documentation Catholique, vol 42, pg. 505).
"Para gerar uma vida nova, só os cônjuges têm direito recíproco sôbre seus corpos, direito exclusivo, intransferivel, inalienável. $E$ isso deve ser assim, em consideração também ao filho. A quem dá a vida a um ser impõe a natureza, em virtude dêsse mesmo vínculo, o encargo de sua conservação e de sua educação. Mas, entre o cônjuge legítimo e o filho, fruto do elemento ativo dum terceiro (mesmo quando consentir o marido), não existe nenhum vínculo de origem, nenhum vínculo moral e jurídico de procriação conjugal.

"4" Quanto à liceidade da fecundação artificial no matri mônio que nos baste, por ora, lembrar êstes princípios de direito natural: o simples fato que o fim visado é obtido por tal meio não justifica o emprêgo de tal meio; nem o desejo, em si mui legítimo, nos cônjuges, de ter um filho, basta para provar a legitimidade do recurso à fecundação artificial que realizaria tal desejo.

"Seria falso pensar que a possibilidade de recorrer a tal meio pudesse tornar válido o matrimônio entre pessoas não aptas para o contrair pelo fato do impedimentum impotentiae.

"Por outro lado, é supérfluo observar que o elemento ativo não pode jamais ser obtido lìcitamente por meios contra a natureza.

"Ainda que não se possa a priori excluir novos métodos, só pelo motivo de sua novidade, no que diz respeito, no entanto, à fecundação artificial, não sòmente se deve ser extremamente reservado, mas é preciso absolutamente afastá-la. Falando assim não se repele necessàriamente o emprêgo de certos meios artificiais destinados ùnicamente a facilitar o ato natural ou a fazer $o$ ato normalmente realizado conseguir seu fim" (28).

Lapidar essa definição de princípios que, sem descer ao casuismo dos pormenores, fixa preceitos de ordem geral, lògicamente aplicáveis às hipóteses concretas.

10. Falando às parteiras, a 29 de outubro de 1951, PIO XIl assim se pronunciou, acentuando sua repulsa, mesmo na inseminação homóloga, a tudo o que venha a separar a procriação do ato conjugal normalmente consumado:

"Reduzir a coabitação dos cônjuges e o ato conjugal a uma pura função orgânica para a transmissão dos germens seria como converter o lar doméstico, santuário da família, num simples laboratório biológico. Também em nossa alocução, de 29 de setembro de 1949, ao Congresso internacional dos médicos católicos, excluimos formalmente do casamento a fecundação artificial. $\mathrm{O}$ ato conjugal, em sua estrutura natural, é uma ação pessoal, uma co- 
operação simultânea e imediata dos cônjuges, a qual, pelo próprio fato da natureza dos agentes e do caráter do ato, é a expressão do dom recíproco, que, segundo a palavra da Sagrada Escritura, realiza a união numa só carne" (29).

11. Precisando ainda mais sua lição a respeito do tema que nos ocupa, ao receber em audiência especial, a 19 de maio de 1956, os membros do 2 Congresso mundial científico da fertilidade e da esterilidade, que se realizou em Nápoles, pronunciou Sua Santidade o Papa PIO XII em francês (salvo uma passagem em latim, devido à extrema delicadeza do assunto) uma importante alocução, em que, após dissertar sôbre o aspecto social da esterilidade, enfrentou, com sua costumeira coragem, os aspectos morais do pretenso remédio a ela, que seria, no entender de vários, a fecundação artificial, afirmando que "o filho é o fruto da união conjugal, quando ela se exprime em plenitude pelo exercício das funções orgânicas, das emoções sensiveis a êle ligadas, do amor espiritual e desinteressado que o anima" (30), e que "nunca é permitido separar êsses diversos aspectos a ponto de excluir positivamente quer a intenção procriadora, quer a relação conjugal" (31)

Proclama, pois, o Papa, além do que já dissera em ocasiões anteriores, que "a fecundação artificial ultrapassa os limites do direito que os cônjuges adquiriram pelo contrato matrimonial, isto é, o de exercer plenamente sua capacidade sexual natural na realização natural do ato matrimonial. $\mathrm{O}$ contrato em questão não lhes confere direito à fecundação artificial, porque tal direito não é de modo algum expresso no direito ao ato conjugal natural e não poderia ser dele deduzido" (32), concluindo que a fecundação artificial "viola a lei natural" e "é contrária ao direito e à moral" (33).

Apresentando com tal precisão seu pensamento, o Sumo Pontífice elucidou que considera ilícita a fecundação artificial pròpriamente dita, e sòmente lícita a fecundação artificial imprópria, isto é, "o emprêgo de certos meios artificiais destinados ùnicamente a facilitar o ato natural ou a fazer o ato normalmente realizado conseguir seu fim" (34), que é a fecundação.

Portanto, PIO XII chama de inseminação ou fecundação artificial apenas a pròpriamente dita, que é ilícita.

Parece também que o Sumo Pontífice da Igreja Católica reputa admissíveis tão sòmente os dois primeiros métodos de inseminação artificial imprópria, acima apontados pelo Prof. PEIRO', ou, quiçá, apenas o primeiro.

12. RAYMOND RAMBAUR, autor duma magnífica obra, Le drame humain de l'insémination artificielle, em que versa eruditamente os dados médicos e os problemas legal e jurídico, mora e individual, social e político da matéria, concluindo pela antevisão de perspectivas futuras, apresenta-nos também o ponto de vista protestante, citando o estudo dum grupo de teólogos luteranos suecos da Faculdade de Teologia de Upsal opinando pela condena ção da hétero-inseminação, mas silenciando sôbre a auto-inseminacão, aludindo também aos pareceres dos pastores GEORGES MAR. CHAL (francês) e HARALD REISENFELD (sueco), contrários à hétero-inseminação, não informando claramente em que condições admitem a auto-inseminação (35). Expõe também o ponto de vista israelita - condenação da heteróloga e diversidade de opiniões, quando à homóloga (36) - e alude ràpidamente ao desinterêsse, por óbvios motivos religiosos, do muçulmano pelo proplema (37).

13. Condenando a hétero-inseminação, a Academia de Ciências morais políticas da França, em resolução de 9 de maio de 1949, depois de aludir às objeções do ponto de vista moral, jurídico e social, chamou a atenção para os inconvenientes de ordem psicológica que nem sempre podem ser objeto de reflexão no momento de decidir, em que se acham embotadas as faculdades de apreciação dos interessados, surpreendidas e desconcertadas pela estranheza do processo, o que torna contestável a autorização marital, concluindo que "o fato de integrar fraudulentamente numa família um filho, que usará o nome do pai legal e que se acreditará seu filho, deve ser considerado como atentatório às bases do casamento, da família, da sociedade" (38).

GABRIEL MARCEL mostra a situação burlesca do marido que se associa à operação inseminatória heteróloga com seu financiamento e consentimento, e pergunta se êle não sentirá ciúme do doador anônimo e, mesmo na hipótese negativa, se tal insensibilidade chegará até o ponto da inconsciência, que não enxergue a desigualdade entre seu papel de complacência e o decisivo da mulher, mormente quando surgir o "filho de pai desconhecido" (39), que não poderá ter por êle, quando descobrir o segrêdo de seu

(35) RAMBAUR, o. c., pgs. 166-170.
(36) RAMBAUR, o. c., pgs. 171-173.
(37) RAMBAUR, o. c., pgs. 174-177.

(37) RAMBAUR, o. e., pgs.174-177.

(1) 
nascimento, o respeito conveniente. $O$ eminente filósofo repele vigorosamente a assimilação da inseminação a uma transfusão de sangue ou a uma inoculação qualquer, pois seria esquecer o caráter fundamental específico do esperma como tal — "êle veicula uma história" (40).

Em uma de suas crônicas diárias, sob a epígrafe de "Jornalzinho pobre", a escritora patrícia DINAH SILVEIRA DE QUEIROZ chama a inseminação artificial de "tristíssimo carnaval científico", "tremenda hiprocrisia humana" e "contrafação do direito de criar, que é um direito divino", acrescentando:

"A inseminação artificial é o produto de uma idéia falsa a respeito do casamento.. Afinal, perante a vida, o que há de mais importante no matrimônio é o filho. Se êsse filho vier, pela inseminacão artificial, de um outro pai e não daquêle que lhe vai dar o nome, se quebra assim a longínqua tradição da família, será possivel, graças à inseminação artificial, que coisas espantosas ocorram, como o incesto legal. Se os próprios pais legais da criança não sabem de quem é ela filha, como poderão impedir amanhã o incesto, se por uma dessas circunstâncias da vida, irmãos se venham a encontrar e se sintam atraidos um pelo outro? Sabe-se, por outro lado, que a inseminação artificial chega às vêzes a provocar, na mãe, verdadeiras neuroses. Ela é honesta, ela é boa. Mas tem um filho... . e não sabe de quem" (41).

$O$ pediatra inglês PARSONS adverte aos eugenistas que estão trabalhando "para produzir uma sociedade tal que ninguém possa mais estar seguro de sua própria origem ou da de outrem" (42).

14. No clima de inversão de valores e de desconhecimento dos direitos naturais do homem, que é o triste apanágio dos regimes totalitários (quer seja, no recente passado, o nazismo, quer, no presente, o comunismo), são de esperar todos os excessos. Assim como Hitler impunha a esterilização a um de seus logarestenentes, Himmler, convidava as Fräulein a se entregarem aos sol-

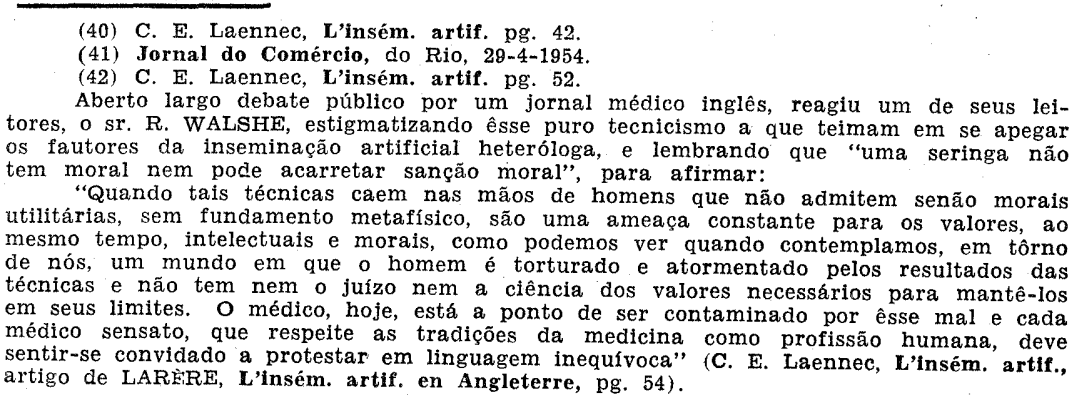

dados (43), o comunismo não vacilará, para a produção em massa de "carne para canhão", em tornar obrigatória a inseminação artificial generalizada e planejada, forçando a tal a mulher, o doador e o médico. Quanto ao marido - quantité négligeable - nem se cogitará dele. ficial?

Detivemo-nos demais no aspecto moral da inseminação arti-

15. E' que, se é certo que a inseminação homóloga, quando praticada do modo chamado impróprio, só pode ter repercussão no campo jurídico, quanto à responsabilidade médica, por exemplo, em casos de imperícia na inoculação seminal, ou de violência, ou de fraude, transformando-a em heteróloga, se o médico, ao em vez de utilizar o líquido do marido, inoculasse o dum doador (44), não menos certo é que, não só a inseminação heteróloga, como mesmo a homóloga própria, interessam fundamentalmente o direito, tanto o penal, como o civil, e neste, o familiar e, por via de conseqüência, o sucessório, pela profunda revolução que nele operam, de vez que os codificadores do direito moderno não podiam levar tão longe sua previsão até cogitarem de tão insólito processo de geração.

Ora, para abordar o aspecto jurídico, não nos era lícito postergar o lado moral, entendendo, mesmo, que, para a firme repulsa que o direito deve opor a certos processos de inseminação artificial, bastaria o fato de serem êles imorais em si.

16. O Código Civil Brasileiro, apesar de elaborado em época de extremado individualismo liberal e - podemos, mesmo, acentuar - da latitudinarismo agnóstico, não deixou de ser informado de princípios éticos, tanto assim que, exemplificando, mui de relance, restringe os atos jurídicos apenas aos lícitos (art. 81), fulmina com a nulidade aquêles cujo objeto for ilícito (art. 145,

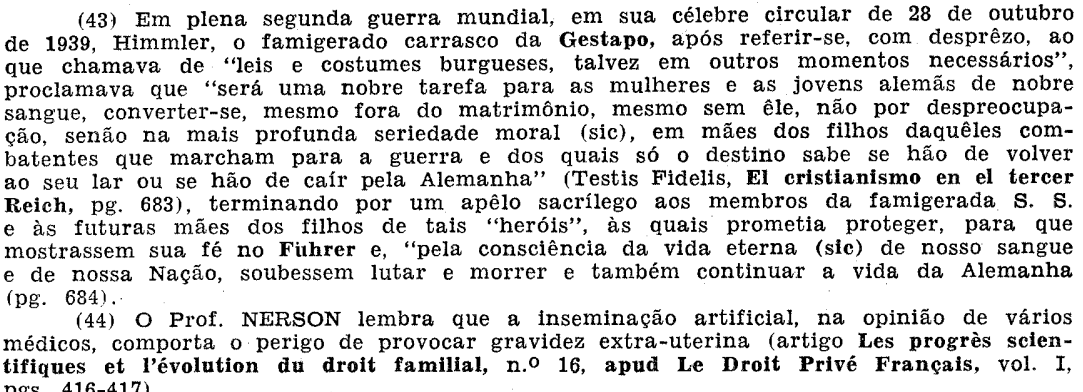

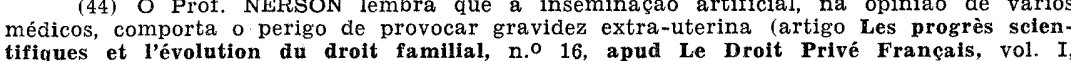
tifiques et l'érol
pgs. $416-417$ ). 
$\mathbf{n}^{\circ}$ 2), nega o direito à repetição àquêle que deu algo para fim ilícito, imoral ou proibido por lei (art. 971).

Especialmente, no direito de família, o laicismo predominante se deteve, por vêzes, respeitoso, ante o caráter sacro do ma trimônio e das relações familiares, influenciado ainda pelo "perfume do vaso quebrado", de que falava Renan.

$\mathrm{O}$ método de utilizar semen do marido pelo processo imoral ha masturbação, além do perigo de engano ou fraude pelo emprêgo ceitos dos arts. $337,338,339,340$, 363 , revolucionando os consileiro, similare $33,338,339,340$ e 363 do Código Civil Brae 340 do Código Civil Francês, a que aludem os estudos de RAYMOND RAMBAUR e dos
Professores SAVATIER e NERSON.

17. O Código Civil Brasileiro, seguindo a tradição do direito romano - pater is est quem nuptiae demonstrant direito transplantada para seu art. 337, baseou todo o demonstrant (45), de filiação legítima nas presuncões concebidos na constância sunçôes legais da legitimidade dos filhos dos mesos na constância do casamento (art. 337) e da concepção (46) (46), desde que tenham nascido, no mínimo, 180 dias depois de estabelecida a convivência conjugal (art. $338, n^{\circ} 1$ ), mas sempre dentro nos 300 dias subseqüentes à dissolução da sociedade conjugal, por morte, desquite ou anulação (art. $338, \mathbf{n}^{\circ} 2$ ). Êsse sistema se aplica, por analogia, à filiação ilegítima e 2).

Assim, o legislador pátrio permitiu, no art. 340 , ao marido o direito excepcional e privativo de contestação de legitimidade do filho nascido de sua mulher apenas no caso de impitimidade do de coabitac̃̃ tes legalmente

Essa impossibilidade física ocorre, não só no caso de impotência absoluta (art. 342), ou no de enfermidade que impossibilite relações sexuais, como também no de ausência.

Com a inseminação artificial própria, a ausência, já de si, como motivo legal, muito reduzida, em face a ausencia, já de si, municações pela aviação, ficará pràticamente anulada pela prova da inseminação artificial com esperma do marido, mesmo noutro extremo do orbe, servindo, quiçá, na guerra da Coréia, desde que se use o imoral processo da masturbação.

Por isso, SAVATIER, que repele enèrgicamente a idéia de

\footnotetext{
(45) Dig., L.o 2.0, tit. 4, fr.. 5
(46) Dig., L.0 1.0, tit. 5, fr. 12.
}

valorizar a inseminação artificial, dela fazendo "uma instituição jurídica, de certo modo, concorrente do casamento", entende que "o futuro direito civil não pode sistemàticamente negá-la", atendo-se à regra do art. 312 do Código Civil Francês, idêntica à do art. 340, $\mathrm{n}^{0} 1$, do nosso Código Civil, relativa à impossibilidade física de coabitação dos cônjuges, de vez que "seria tão absurdo tapar os olhos sôbre a possibilidade duma inseminação artificial como sôbre a duma filiação natural" (47)

A hétero-inseminação, além de introduzir na família um intruso adulterino, futuro abocanhador de herança, quando praticada em mulher casada, sem ciência do marido, poderá, em qualquer hipótese, ser responsável por uma filiação incestuosa, utilizando semen de doador que seja parente em grau próximo, quiçá pai, filho ou irmão.

18. O eminente catedrático de Direito Civil da Faculdade de Direito de Poitiers pleiteia uma revisão do art. 312 do Código Civil Francês, no que se refere à contestação de legitimidade, para atender à hipótese de proceder o marido, à distância, com líquido seu, à inseminação de sua mulher, de acôrdo com ela e com o concurso de especialistas, apontando o perigo de vir êle, depois, a cometer a deslealdade, de, amparado no atual preceito legal, contestar a paternidade (48).

Já em 1918, o saudoso Prof. JOÃO ARRUDA, catedrático de Direito Civil da Faculdade de Direito da Universidade de S. Paulo, considerava a possibilidade da geração de filhos legítimos, ilegítimos e espúrios, por fecundação artificial (49), e, mais recentemente, o eminente Prof. ALMEIDA JÚNIOR, catedrático de Medicina Legal da mesma Faculdade, em seu livro Paternidade (aspectos biopsicológico, jurídico e social), abordava o problema da fecundação artificial e suas repercussões sôbre o sistema de presunções legais de nosso Código Civil, qualificando a fecundação artificial heteróloga como "uma forma insólita de adultério - adultério científico" (50).

SAVATIER entende também oportuna uma revisão do art. 340 do Código Civil Francês, similar do art. 363 do nosso, "pois

(47) SAVATIER, Les métamorphoses économiques et soctales du Droit Clvil d'aujourd'hui, n.o 173, pgs. 135-136. A respeito das consequências jurídicas da inseminação

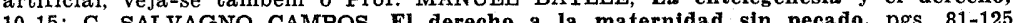

(48) SAVATIER, O.

(49) Apud Revista de Direlto, vol. 48, pgs. 293-295.

(50) ALMEIDA JR., Paternidade, pgs. 140-144. Cfr. estas palavras de MICHEL RIQUET: “Adivinha-se também, sem que haja necessidade de aqui insistir nisso, a intornar-se mãe por um outro que não o seu próprio marido, mesmo quando êsse adultério artificial se realiza à distância, por mẹio duma técnica veterinária". (MICHEL RI- 
se um pai natural confessou seu filho, quer diretamente, quer por escrito inequívoco, quer implìcitamente, contribuindo como pai para sua criação e educação, a distância, em que estava, da mãe, à época da concepção, não pode mais constituir uma exceção absoluta contra a ação de investigação de paternidade" (51), eis que, em face da inseminação artificial, a confissão conserva seu valor probatório.

Coerente com seus princípios morais, convicto de que "várias grandes idéias, mesmo quando informuladas, estão claramente subjacentes às regras de nosso direito civil e penal, em matéria de relações sexuais, e, especialmente, de inseminação", e de que tais idéias, "oriundas do direito natural, são, em certo sentido, anteriores ao cristianismo" (52), e de que "é vantajoso aos filhos nascer de pessoas casadas, isto é, dum casal que, de antemão, tenha, em face dos filhos a nascer, tomado compromissos públicos e indissolúveis" (53), SAVATIER pensa dever limitar-se a reforma, ou melhor, a revisão do Código napoleônico, velho de um século e meio e em vias duma reforma completa em outros setores, apenas aos dois textos dos arts. 312 e 340 , pois lhe "parece inútil e inoportuno introduzir nele textos para permitir especialmente a prova duma tal paternidade" (54).

E justifica que, exigindo a inseminação artificial "uma preparação e uma técnica que não lhe poderiam conservar o caráter íntimo e secreto duma conjunção sexual" (55), ficaria a prova, até certo ponto, facilitada, não convindo que o legislador intervenha positivamente para acentuar tal facilidade, mas bastando manter sua abstenção, que deixará de ser ignorância, pois, "dum lado, o respeito legal do segrêdo do ato sexual é estritamente ligado à salvaguarda do pudor e da dignidade humana", e, "doutro lado, não se pode, fora do casamento, remontar ao doador senão pelo conduto duma série de segrêdos médicos", sendo, de todo, inconveniente não destruir tais óbices legais e deontológicos, concluindo o eminente mestre que, "sob regime de liberdade humana, as mulheres tentadas pela inseminação artificial ficarão seguramente pe-

(51) SAVATIER, Les métamorphoses, n.o 173 , pg. 136 . "E qual nao sera, por outro lado - diz RAMBAUR - o embarą̧o dos magistrados do art. 340 do Código Civil, uma carta em que o suposto pail lembrasse formalmente $a$ mãe que, por exemplo, a hétero-inseminação combinada se faria em tal dar, a tal hora, numa época compreendida
main de l'ins. art., pg. 77 .

(52) Apud C. E. Laennec, L'tnsém. artif., pg. 25.

en Droit Civil d'aujourd'hui, apud Le

(54) SAVATTER, Les métamorphoses, n.o 173, pg. 136.
(55) SAVATIER, o. e., n.o 172 , pgs. $136-137$. queno número, em comparação com as tentadas pelo amor" (56).

19. Existe em nosso direito positivo, como no da maioria dos povos, um instituto jurídico, já disciplinado desde o direito romano - a adoção - que resolve o problema de dar, artificialmente, filhos a quem os não tem, sem ofender a moral, sem burlar a realidade.

Bastaria para que tivesse êle maior aplicação na vida real dos nossos dias, que se introduzissem algumas reformas acautelatórias e se recuasse um pouco o limite mínimo de idade dos adotantes, estabelecendo, ao mesmo tempo, para que se facultasse seu uso, um mínimo legal de duração de vida conjugal sem gerar filhos. Recente projeto apresentado no Parlamento viria propiciar, se convertido em lei, essa facilidade almejada.

20. Que, moralmente, constitua adultério a hétero-inseminação, em que um ou ambos - doador e mulher inseminada - são casados, só mesmo, por diminuicão de senso moral, poderá ser negado. Se o doador é casado, está dispondo de seu germen para gerar filho cuja paternidade poderá ser reconhecida, voluntária ou judicialmente, nos termos dos arts. $1^{\circ}$ e $4^{\circ}$ da lei $n^{\circ}$ 883 , de 21 de outubro de 1949 , e para os efeitos dos arts. $2^{\circ}, 3^{\circ}$, $5^{\circ}$ e $9^{\circ}$ da mesma lei.

"Em matéria de direito civil, - escreve SAVATIER - a inseminação artificial pode propor, pouco mais ou menos sôbre todos os pontos, as mesmas questões que as relações sexuais. Assim, o fato, seja quanto ao marido, seja quanto à mulher casada, de se prestar a ela em face de terceiro, permitirá ao outro pedir, na lei atual, separação de corpos ou divórcio (57). Porque a

(56) SAVATIER, o. c., n.o 172 , pg. 137.

idade com que pretendem muitos justificar a prática imoral da hétero-inseminacão, não só em mulheres casadas, como também em solteiras e viúvas, JAIME PUJIULA escreveu que a virgindáe é nua das virtudes ciedade cousa reconhecida mesmo antes do cristianismo. As virgens consagradas a Deus devem considerar-se verdadeiras e carinhosas mães dos desgraçados. Que seria de tantos infelizes que constituem um como lastro da sociedade, de tantos pobres, desque, com amor de caridade e carinho, se sacrificam por êles, libertando a mesma sociedade dum carinho que não hes pode prestar senão por meio dessas heroinas da caridade e do sacrificio? As casas de beneficencia, os asilos, os hospitais e outras instituicóes religiosas são como verdadeiros esteios da mesma sociedade nos povos católicos",
(artigo La inseminación y su trascendencia, apud Digesto Católico, Buenos Aires, n.o 62, pg. 77 .

Convém não esquecer que, como diz o Dr. RENE" BIOT, "a saúde não é o bem supremo e que a infencundidade dum lar nẫo acarreta sua ruína moral e espiritual, poo devotamento" (Dr. RENE' BIOT, offensives biologiques contre le persone, pg. 177). "O desejo, tão legitimo e tão nobre, de ter um filho, está sujeito, no entanto, a limites e é preciso - digo-o com a mals comovida simpatia pelos que sofrem tal provação (57) SAVATIER fala de conformidade com o direito positivo francês. No Brasil, diriamos que permite o desquite, nos termos do art. 317 no 1 (adultério) ou n.o a 
inseminação artificial é assimilável ao adultério pròpriamente dito, e constituiria, em todo caso, aos olhos da jurisprudência, uma injúria para o outro cônjuge. Há falta certa à promessa de dom exclusivo, que êsse último recebera, da pessoa de seu cônjuge" (58).

Entre nós, dada a orientacão jurisprudencial de ir buscar 0 direito civil a conceituação legal do adultério no direito penal, e dada a conceituação doutrinária dominante, a que êste se reporta, de exigir a realização da conjunção carnal, parece-nos que, em face de nosso direito positivo, tanto civil como penal, não se configura na hétero-inseminação o adultério.

21. No entanto, evidentemente, a hétero-inseminação artificial importaria sempre em injúria grave ao outro cônjuge, motivo legal para o desquite (art. $317, \mathrm{n}^{\circ} 2$, do Código Civil), pois, de vez que, em face do art. 240 do Código Penal vigente, não há mais a distinção que o $\S 1^{\circ}$ do art. 279 do anterior fazia entre o adultério do marido e o da mulher, dando margem a que a doutrina e a jurisprudência enquadrassem o adultério escandaloso do marido na injúria grave, para efeito de desquite, não há, hoje, por que, lògicamente, fazer distinção entre injúria grave do marido à mulher e desta àquêle.

22. SAVATIER considera estupro a inseminação artificial efetuada à fôrça (59). Em face de nosso Código Penal, tal não é possível, porque o art. 2.13 exige, para a configuração de tal crime, além dos requisitos de violência ou grave ameaça, a conjunção carnal $(60)$.

Nem por isso, ficaria impune tal violência, pois se enquadraria, conforme as circunstâncias e conseqüências, na lesão corporal (art. 129 e seus $\S \S 1^{\circ}$ e $2^{\circ}$ ), na periclitação da vida ou da saúde (arts. 130, 131 e 132), no atentado ao pudor por violência (art. 214). Quando a inseminação tivesse sido feita mediante fraude (art. 216), teríamos o crime de atentado ao pudor. Quando praticada numa menor, constituiria o crime de corrupção de menores

(58) Apud. C. E. Laennec, L'ins. artif., pgs. 30-31.

(59) "Porque, no estrupo, o que reprova essencialmente a lei não é a cópula mesma, mas a violência do que o sêr feminino tem de mais intimo e de mais reservado, do que contra sua vontade, para uma inseminacão artificial tal como impondo-lhe cópula contra sua vontade. $E$ as consequências sociais do primeiro dêsses atos não serão menos graves do que as do segundo" (SAVATIER, apud C. E. Laennec, L'insém. artif., pgs. 27-28). (que precose praticada por agente feminino (parteira, enfermeira, etc.), se chegaria ao absurdo burlesco duma mulher estuprando a outra. A resposta de RAMBAUR a tal objeção é

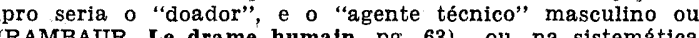
do nosso atual Código Penal Brasileiro, co-autor. (art. 218). Quando, para obter a inseminação artificial, se tivesse recorrido ao rapto, teríamos a figura criminal do rapto violento ou fraudulento (art. 219) ou do consensual (art. 220), diminuida apenas na hipótese do art. 221, ou aumentada, na do art. 222, do concurso com outro crime.

Quando da violência da fecundação artificial resultar lesão corporal de natureza grave, teremos o delito do art. 223, presumindo-se violência nas hipóteses do art. 224 , isto é, se a vítima:

a) não é maior de 14 anos;

b) é alienada ou débil mental, e o agente conhecia esta circunstância;

c) não pode, por qualquer outra causa, oferecer resistência.

Quando praticada em lugar público, ou aberto, ou exposto ao público, estaremos diante dum crime de ultrage público ao pudor (art. 233).

23. Parece-nos que, em face da brutal realidade, que é o processo da inseminacão artificial, com tremendas repercussões no campo criminal, se impõe, a par da manutenção das formas qualificadas do art. 223 e seu $\S$ único, das presunções legais do art. 224 (violência ficta), do procedimento do art. 225 e do aumento de penalidade nas hipóteses do art. 226, também uma atualizacão do nosso Código Penal, para equiparar a inseminação artificial heteróloga ao adultério, e quando acompanhada de vioartificial heteróloga ao adulterio, e quando acompanhada de viocom fraude, à posse sexual mediante fraude, e quando praticada contra virgem de 14 a 18 anos, à sedução.

Mesmo de jure constituto, o facto da dificuldade de prova, principalmente em matéria penal, devido ao sigilo profissional a que está sujeito o médico pelo art. 154 do Código Penal (61) e que deve ficar inviolável, não seria motivo para preconizar a impunidade.

24. E aqui surge o problema cruciante da responsabilidade do médico. Como deve comportar-se êle, em face dêsse novo processo que revolucionou a ciência biológica e cujas repercussões sôbre a moral e o direito estamos a examinar? Deve prestar sua cooperação à inseminação artificial?

(61) Na França existe o Código de deontologia médica, com caráter oficial ex vi vol. 44. pgs. 973-984), que, em seu art. 4.0, impôe a todo médico o segrêdo profissional, alvo derrogaçoes estabelectas pela lei. Disposição idêntica contém o art. 4.0 do Cólgo de domtologa das parteiras, tambem com carater orclal, ex vi do art. 1.0 do de1359-1366). 
"O exercício da medicina é um ministério - diz o art. 10 do Código francês de deontologia médica - não deve ela, em caso algum, nem de qualquer forma, ser praticada como comércio".

"A dignidade de sua função - pondera RAMBAUR - impõe ao médico ater-se, o mais estritamente, à técnica médica, repudiar, tanto quanto possível, êsse ofício subalterno e subreptício, que espanta tão fortemente Hipócrates nos infernes, de empresário de casamentos clandestinos, de corretor de noivo ou de amante com esguichos tarifados". (62).

Depois de se referir à preocupação que, em tema de inseminação artificial, se propaga na Inglaterra, no sentido de proteção ao médico, à mãe, ao filho, à família e... a S. Ex. o doador, de advertir aos médicos do perigo de responsabilidade civil, que incorrem, em face da mãe, quando a experiência prejudicar a saúde ou a situação familiar desta; em face do marido e da família do filho, quando a atribuição duma sucessão correr o risco de ser falseada pelo emprêgo do processo, e, mesmo, em face do doador, se a paternidade dêste vier a pô-lo em dificuldade ou a lhe impor compromissos imprevistos, e de aludir às precauções de ordem jurídica apontadas no trabalho do Dr. RAOUL PALMER (63), o Professor SAVATIER, na primeira de suas conferências sôbre responsabilidade médica, proferidas na Universidade de Louvain, opinou que essas tentativas de escapar à responsabilidade, na França, constituiriam processo ilusório, em face da hostilidade da jurisprudência às cláusulas de irresponsabilidade, mormente na seara da medicina, em que a irresponsabilidade repugna, por interessar de perto o corpo e o espírito do homem, bem como a tôda a organização da família, matéria essencialmente de ordem pública" (64).

RAMBAUR alude ao perigo para o médico, na hipótese de ser o doador um tarado, o que faria aquêle incorrer na sanção do art. 320 do Código Penal Francês.

$\mathrm{O}$ médico está sujeito às penas da autoria, em qualquer dos crimes acima apontados do Código Penal Brasileiro, e às de coautoria (art. 25), quando concorrer para algum deles.

62) RAMBAUR, Le drame humain de l'insém. art., pg. 85

(62) RAMBAUR, Le drame humain de l'insém.
(63) C. E. Laennec, L'insém, artif., pgs., 21-24.

SEYMOUR, nos Estados Unidos, chega a preconizar escrituras de consentimento
inseminaçấo, das quais apresenta formulários, e nas guais os para inseminaçấo, das quais apresenta formulários, e nas quais o marido dará seu esperma de homem escolhido pelo dito profissional, tudo isso com firma reconhecida mpressões digitais dos dois polegares do marido, após o que o tabelião certificará, na orma la usada, a apresentaçao do marto e da mull Aconselha êle ainda ao médico obter consentimento escrito do doador e da mu-
her dêste, se for casado, e não partejar a mulher em quem tiver operado a inseminacão
artificial (apud RAMBAUR, o. c., pg. 82). São edificantes os eserúplos (?!) de ética êsses conselhos... S.

Imagine-se o que não inventaria de formalística
(64) SAVATIER, La responsabilité médicale, pg. 20.
Além disso, terá contra si as agravantes da letra $h$ do art. $44, \mathrm{n}^{\circ} 2$ (violação de dever inerente à profissão), dos ns. 1 (promoção ou organização da cooperação no crime ou direção da atividade dos demais agentes) e 4 (execução do crime, ou participação nele, mediante paga ou promessa de recompensa) do art. 45, além da reincidência (art. 44, $\mathrm{n}^{0} 1$ ), podendo ocorrer também o caso de crime continuado (art. $51, \S 2^{\circ}$ ).

Em matéria de atenuantes, salvo coação de que tenha sido vítima (art. 48, $\mathrm{n}^{\circ}$ 4, letra $c$ ) e confissão espontânea (letra $e$ ), não vemos outras que possam aproveitar ao médico, pois nunca poderá sustentar com êxito o absurdo de ter cometido o crime por motivo relevante de valor social ou moral (letra $a$ ).

Quando muito poderá responder apenas por crime culposo (art. 54), se tiver agido com o consentimento do doador, do marido, da mulher casada, ou da mulher solteira ou viúva, todos êles pessoas capazes.

$\mathrm{O}$ médico, pelo art. 27 do Código francês de deontologia médica, pode, mui legitimamente, recusar sua atuação em qualquer inseminação artificial, pois jamais poderá invocar-se para ela urgência, nem deveres de humanidade:

"Fora do caso de urgência e do em que faltasse a seus deveres de humanidade, um médico tem sempre o direito de recusar seus cuidados por razões profissionais ou pessoais".

25. Longe de nós a pretensão de ter esgotado o assunto neste simples e ligeiro ensaio, em que utilizamos os parcos subsídios da escassa literatura especializada existente, que nos foi dado compulsar em breve lapso de tempo, em meio a absorventes trabalhos. Apenas afloramos, como cultor do direito, o tema, quase inexplorado no nosso meio jurídico, (65) com o fito de convocar os estudiosos ao debate do mesmo, pois nos repugna a estúpida política do avestruz, escondendo a cabeça para não enxergar o perigo.

Se, no Brasil, o perigo do incremento da inseminação artificial é menor do que o do abôrto e o do neo-maltusianismo, nos dias que correm, em que o amoralismo ambiente de nossas metrópoles, o grosseiro materialismo, a sêde insofrida e ilimitada de gozos e prazeres, e o comodismo, a par de dificuldades de ordem financeira, fazem preferível a supressão ou a limitação de filhos, não podemos esquecer que é justamente nos países, em que, por causa de

(64) Em seu brilhante discurso como orador oficial da turma de bachareis da Faculdade de Diretto de Pôrto Alegre de 1952, o laureado FERNANDO RODRIGUES ALvol. I, pg. 276). Após a publicação em 1953, na Revista Forense (vol. 149, pgs. $497-507$ ), de
nosso trabalho, ora refundido, apareceu o livro do Prof. ORLANDO GOMES.
A crise do Direito, que consagra o n.o 122 ao problema, sob a eprgrafe 
tais processos, mais tem caído a natalidade (Estados Unidos, Inglaterra e França), que maior aplicação têm tido também as técnicas modernas que visam o efeito contrário, isto é, o da geração de novos seres, passando por sôbre óbices até pouco julgados insuperáveis. Mais uma vez temos o ensêjo de sentir a verdade do provérbio que nos adverte que os extremos se encontram.

Sem perder de vista a realidade e os progressos da ciência, mas orientados pela moral, respeitosos do direito natural, atentos ao interêsse da família, sem olvidar os dados da psicologia, previdentes às repercussões sociais e políticas, cônscios da eminente dignidade da pessoa humana, procedam ao estudo do problema da inseminação artificial os juristas, quaisquer que sejam os setores em que atuem, como magistrados, como mestres do direito, como advogados, como escritores, como legisladores, a fim de que, quando couber a êstes últimos concretizar as reformas convenientes, sejam as mesmas aptas para o serviço do bem comum, alvo colimado por toda a autoridade social.

\section{ENSAIO DE UMA TEORIA ECLÉTICA DA AÇÃO*}

\section{GALENO LACERDA}

Catedrático de Direito Judiciário Civil

1. - Ao trazermos novamente a discussão o angustioso tema da ação processual, supomos definitivamente superadas as posições da teoria civilista e da chamada teoria do direito concreto de agi:

A primeira, reduzindo a ação ao direito subjetivo material, e a segunda considerando-a, apenas, como direito à sentença favorável, não só não explicam o fenômeno da ação infundada, senão que olvidam a função pública da jurisdição e o papel desempenhado pelo Estado na relação jurídica processual.

Sem dúvida, mais próxima da verdade se situa a teoria do direito abstrato de agir, quando conceitua a ação, simplesmente, como direito à jurisdição, e evidencia a independência entre relaçã. jurídica processual e relação jurídica material. Esta tem sido, in discutivelmente, a solução aceita pela grande maioria dos proces sualistas contemporâneos.

Cremos, porém, que êsse brado de autonomia dos processualistas os tenha conduzido ao excesso da construcão teórica de um direito de ação indeterminado e incondicionado.

Com efeito, se a ação é simplesmente o direito à jurisdição, somos forçados a reconhecer que todo e qualquer pedido formulado à autoridade judiciária constitui exercício do direito de agir.

E, desta forma, identificaremos ação com direito cívico de petição.

2. - E' indiscutível que a ação é uma espécie do direito de petição. A posição doutrinária de COUTURE, neste ponto, é in desmanchável. Teve êle o extraordinário mérito de inserir definitivamente o processo no direito constitucional, dando-lhe um: visão e uma dignidade cívico-política até então não pressentidas.

$\left(^{*}\right)$ - Trabalho apresentado às 1as. Jornadas latino-americanas de Direito Pro- 